TAPROBANICA, ISSN 1800-427X. January, 2015. Vol. 07, No. 01: pp. 66-67, pl. 26.

(c) Research Center for Climate Change, University of Indonesia, Depok, Indonesia

\& Taprobanica Private Limited, Homagama, Sri Lanka

www.taprobanica.org

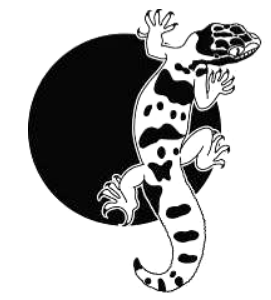

\section{Mating behaviour of the Indian flying fox (Chiroptera) in southern Bangladesh}

Bangladesh is inhabited by 38 species of bats (Order Chiroptera) of which three are frugivorous. One of the latter is the Indian flying fox Pteropus giganteus, a common species in the country (Khan, 2001). The Indian flying fox is widely distributed in South and Southeast Asia from Pakistan to China and as far south as the Maldives Islands (Nowak, 1999). Although the IUCN deems it as a species of Least Concern the population trend is decreasing (Molur et al., 2008).

$P$. giganteus is a social animal roosting in tree colonies in their hundreds and even thousands (Nathan et al., 2005; Kunz, 1982). Flying foxes are long-lived seasonal breeders with a welldefined breeding season that is largely governed by genetic factors (Mcllwee \& Martin, 2002). Despite the fact that $P$. giganteus is a prominent member of Bangladesh's faunal assemblage there is little information available on its reproductive behaviour in the country. In this note we present data on the copulatory behaviour of $P$. giganteus in its natural habitat on Saint Martin's Island, Bangladesh.

During our biodiversity survey of St. Martin's Island $\left(20^{\circ} 38^{\prime} 00.26^{\prime \prime} \mathrm{N}, 92^{\circ} 19^{\prime} 19.12^{\prime \prime} \mathrm{E}\right)$ from 27 February to 1 March 2014, we opportunistically observed mating behavior of $P$. giganteus in a Bombax ceiba tree. The tree was about 20 meters tall and contained a colony of 46 individuals. Twelve individuals (six pairs) were found to display courtship behaviours including mating; three pairs were selected for closer observation. We counted the duration of mating times using a digital stopwatch. Temperature was between $24^{\circ}$ to $29^{\circ} \mathrm{C}$. Photographs and video were captured using a Nikon Coolpix P100 digital camera. St. Martin's is a small island $\left(12 \mathrm{~km}^{2}\right)$ in the Bay of Bengal located approximately $9 \mathrm{~km}$ south of the tip of Cox's Bazaar-Teknaf peninsula and about $8 \mathrm{~km}$ west of the northwest coast of Myanmar at the mouth of the Naf River (Fig. 1). The island has a diversity of flora and fauna.

Observations were carried out during morning hours up to mid-day. Male $P$. giganteus indulged in courtship behaviours prior to copulation. Courting males tried to capture the attention of females by a continuous fanning of their wings while approaching females. This merely had the effect of encouraging the female to escape. Sometimes, though, females had no room to escape and this is when copulation occurred. Although male suitors were rejected at first they were very persistent in following target females. Fifteen to 30 minutes of such determined activity, however, was usually sufficient to "corner" the female such that there was no escape.

Just prior to copulation, the males licked the faces and vaginal regions of the females. The females, for their part, tried to protect the vaginal region with their wings and sometimes even bit the males but the males pushed aside the barrier using the first finger of the wing. During our observations two of the males tried to copulate while approaching the female from the dorsal side but, not surprisingly, failed. In a successful copulation, the male held the female's body by the patagium (Fig. 2) ventrally whilst thrusting himself forcefully; the female's reaction was to attempt to escape while uttering harsh calls. A total of nine observations were recorded where copulation lasted from 36 to 68 (mean 41) seconds. Each mating pair copulated three to five times during each mating incident. Male bats did not release females until copulation was complete. After completion of copulation, females licked their vaginal regions; the males followed. The males also licked their own genitalia. The last copulation lasted longest; afterwards males and females parted company 
moving to different branches. They became silent for the rest of the day.

Copulation in $P$. giganteus has been reported rarely (Cayunda et al., 2004). Earlier studies in India (Tamil Nadu, Uttar Pradesh and West Bengal) found that $P$. giganteus copulates from July to October and gives birth to one or two young from February to April (Koilraj et al., 2001 Mathur et al. 2011; Dey et al. 2013). But Mathur (2011) reported two mating cycle from January to early March and end of September to early August; observations by us in southern Bangladesh corresponded to the mating of the former season.

Our observations correspond with accounts by Koilraj et al. (2001) and Mathur et al. (2011). The latter study found that the male bats licked the scruff, face, and vaginal region of the females after the completion of copulation. However, in our observation, we found males licked the vaginal region of the females before every copulation bout and not in the end i.e. before getting separated from each other. Copulation lasted for about 30-40 seconds and $90 \pm 19.5$ seconds in accounts by Koilraj et al. (2001) and Mathur et al. (2011), respectively, which differ from our findings. Moreover, previous records were from mainland areas whereas our observations are from an island in the Bay of Bengal at sea level.

\section{Acknowledgements}

This research work was supported by the Ministry of Science and Technology, Bangladesh under special research grants for 2012-2013. We thank Amit Kumar Neogi for his support during field work and the Department of Zoology, Jagannath University, Dhaka for instrumentation support.

\section{Literature Cited}

Cayunda, I. E., B. J. C. Ibañez, and S. T. Bastian Jr., 2004. Roosting behaviour and roost site characterization of Pteropus vampyrum in Malagos watershed, Davao City. Agham Mindanaw, 2: 6172.

Dey, S., U.S. Roy, and S. Chattopadhyay, 2013. Distribution and abundance of three populations of Indian Flying Fox (Pteropus giganteus) from Purulia district of West Bengal, India. Taprobanica, 5: 60-66.
Khan, M. A. R., 2001. Status and distribution of bats in Bangladesh with notes on their ecology. Zoos Print Journal, 16: 479-483.

Koilraj, J. A., G. Agoramoorthy, and G. Marimuthu, 2001. Copulatory behaviour of Indian flying fox, Pteropus giganteus. Current Science, 80: $15-16$.

Kunz, T. H., 1982. Roosting ecology of bats. Pp. 1-55. In: Fenton, M. B. and A. G. Marshall (eds.). Ecology of bats. Plenum Press, New York.

Mathur, V., Y. S. Priya., H. Kumar, and V. Elangovan, 2011. Reproductive Behavior and Population Dynamics of Indian flying fox (Pteropus giganteus). Proceedings of Second Seminar on Small Mammal Conservation, 1: 3139.

Mcllwee, A. P. and L. Martin, 2002. On the intrinsic capacity for increase of Australian flying foxes (Pteropus spp., Megachiroptera). Australian Zoologist, 32: 76-100.

Molur, S., C. Srinivasulu, P. Bates, and C. Francis, 2008. Pteropus giganteus. In: IUCN 2014. IUCN Red List of Threatened Species. Version 2014.1. <www.iucnredlist.org>. downloaded on 01 July 2014

Nathan, P. T., H. Raghuram, V. Elangovan., T. Karuppudurai, and G. Marimuthu, 2005. Bat pollination of kapok tree, Ceiba pentandra. Current Science, 88: 1679-1681.

Nowak, R., 1999. Walker's Mammals of The World. The Johns Hopkins University Press, London: 224.

Submitted: 30 May 2014, Accepted: 16 July 2014 Section Editor: Asoka Yapa

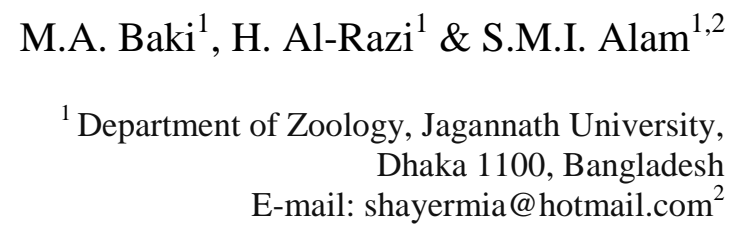




\section{PLATE 26}

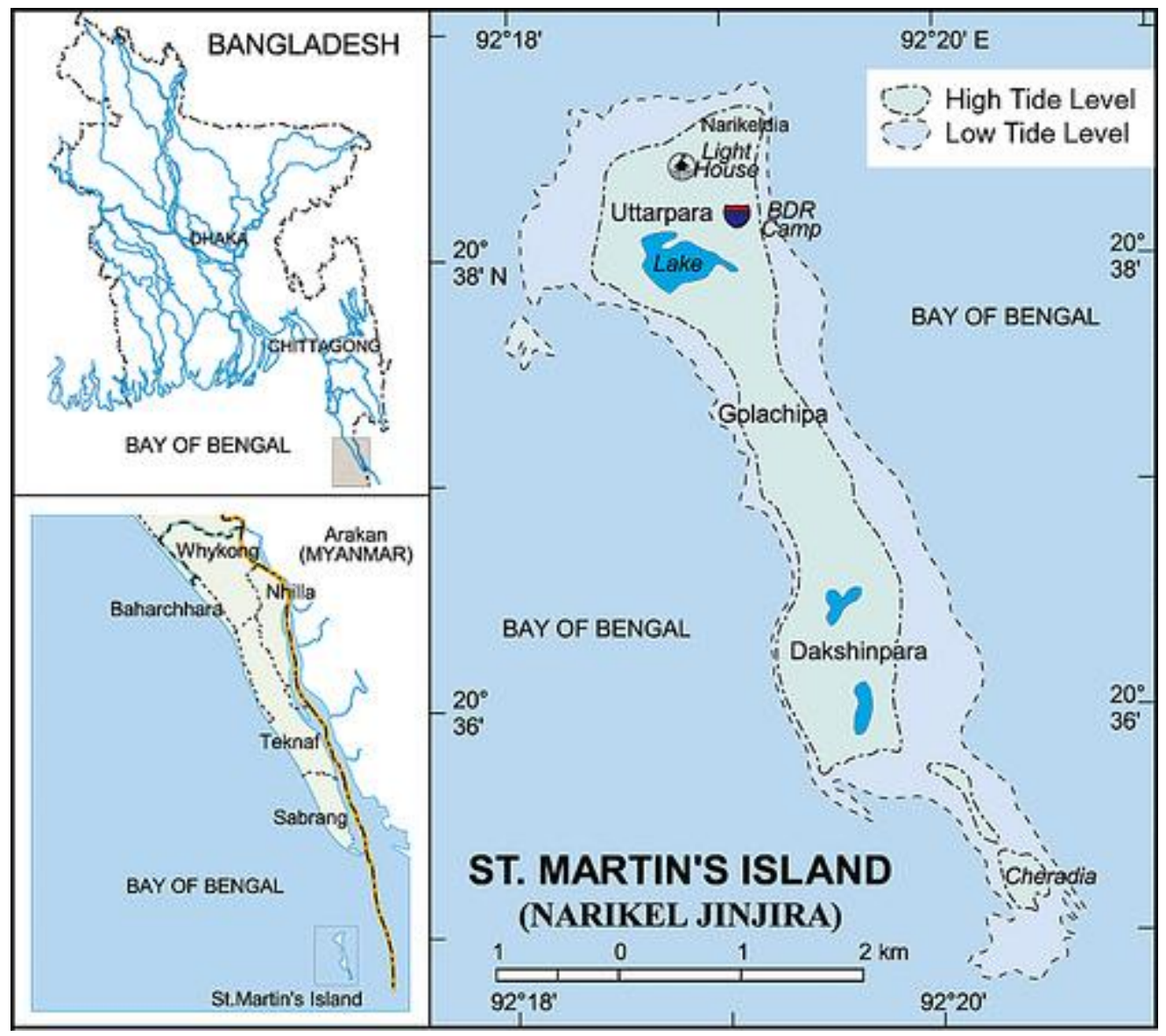

Figure 1: The map of St. Martin's Island, Bangladesh (source: www.banglapedia.org).

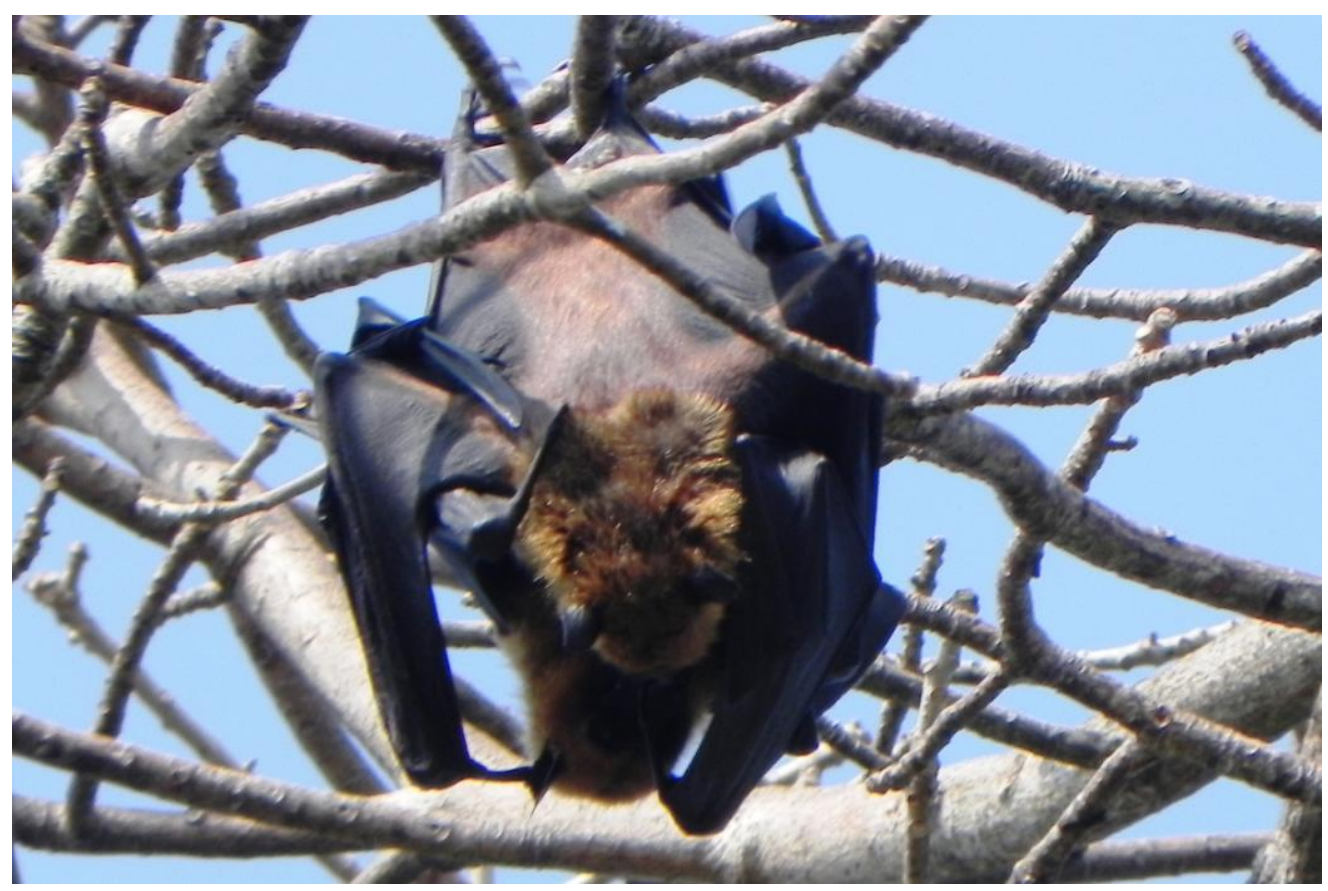

Figure 2: A male flying fox holds a female by its wing. 